\title{
Vulkansk aktivitet på Jorden - nyt fra de sidste 6 måneder
}

Af geolog Susanne Plesner, GeologiskNyt

To relativt ukendte vulkaner har rørt på sig, nemlig Fourpeaked i Alaska og Home Reef - en submarin vulkan, der ligger i det centrale Tonga.

På nær det Indiske Ocean har alle områder, som Jorden er inddelt i nedenfor, oplevet aktivitet fra vulkaner, der enten ikke var aktive eller også kun på vågeblus i første halvår af 2006. Europa er kommet med igen, idet Etna efter et halvt år, hvor den ikke har gjort særligt væsen af sig selv, kom med fornyet udbrud startende i september.

En ret ukendt og uudforsket vulkan ved navn Fourpeaked i Alaska er begyndt at røre på sig, og ved Tonga har aktiviteten fra en submarin vulkan resulteret $i$, at en ny ø har set dagens lys. Disse to vulkaner er valgt ud til nærmere beskrivelse denne gang.

\section{Fourpeaked}

Fourpeaked-vulkanen er beliggende i det

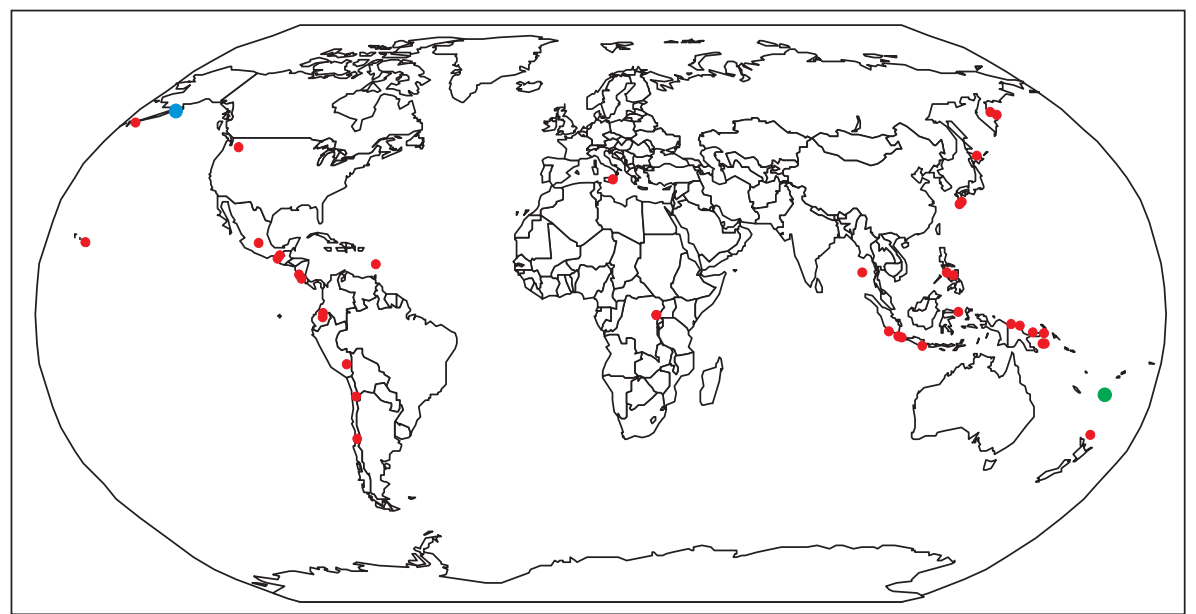

Verdenskort, den med røde fyldte cirkler viser fordelingen af den vulkanske aktivitet de seneste seks måneder. De to omtalte, Fourpeaked og Home Reef, er henholdsvis markeret med en blå og en grøn fyldt cirkel. (Grafik: Forfatteren)

nordøstlige Katmai National Park, Alaska. Den er ikke ret kendt og det, der er synligt af den, består af nogle få blotninger, der omkranser Fourpeaked Gletscheren. Nær den nuværende top er bjergarterne meget hydrotermalt omdannede og denne obser-

\section{Vulkansk aktivitet de sidste 6 måneder}

Nordlige Stillehavsregion

Kilauea, Hawaii, USA

St. Helens, Washington, USA

Cleveland, Aleutian Islands, USA

Atka, Aleutian Islands, USA

Suwanose-Jima, Ryukyu Øerne, Japan

Sakura-Jima, Kyushu, Japan

Miyake-Jima, Japan

Mayon, Filippinerne

Canlaon, Filippinerne

Bulusan, Filippinerne

Taal, Filippinerne

Dukono, Halmahera, Indonesien

Karangetang, Indonesien

Sydlige Stillehavsregion

Semeru, Java, Indonesien

Merapi, Java, Indonesien

Tengger Caldera, Java, Indonesien

Talang, Sumatra, Indonesien

Bamus, Papua Ny Guinea

Bagana, Papua Ny Guinea

Langila, Papua Ny Guinea
Rabaul, Papua Ny Guinea

Ulawun, Papua Ny Guinea

Manam, Papua Ny Guinea

Sulu Range, Papua Ny Guinea

Ritter Island, Papua Ny Guinea

Lopevi, Vanuatu

Raoul Island, New Zealand

Home Reef, Tonga

Mellemamerika, Mexico, Vestindien

Arenal, Costa Rica

Poás, Costa Rica

Turrialba, Costa Rica

Colima, Mexico

Popocatépetl, Mexico

Fuego, Guatemala

Santa María, Guatemala

Pacaya, Guatamala

Soufriere Hills, Montserrat

Sydamerika

Tungurahau, Ecuador

Sangay, Ecuador
Galeras, Columbia

Lascar, Chile

Ubinas, Peru

Nordamerika

Augustine, Alaska, USA

Fourpeaked, Alaska (USA)

Rusland

Karymsky, Kamchatka

Shiveluch, Kamchatka

Indiske Ocean

Piton de la Fournaise, Réunion

Barren Island, Indien

Afrika

Nyamuragira, Demokratiske Republik

Congo

Europa

Etna, Italien 
